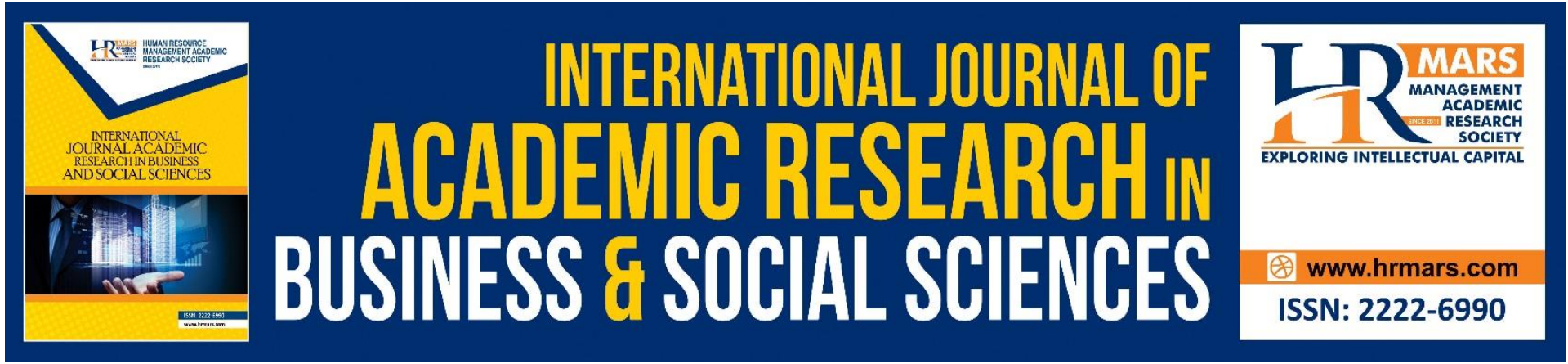

\title{
The Synergy of Distributed Leadership towards District Education Office Performance
}

\section{Zahariah Ismail, Wan Abd Aziz Wan Mohd Amin, Abdullah Derahman}

To Link this Article: http://dx.doi.org/10.6007/IJARBSS/v11-i8/10739

DOI:10.6007/IJARBSS/v11-i8/10739

Received: 16 June 2021, Revised: 20 July 2021, Accepted: 31 July 2021

Published Online: 11 August 2021

In-Text Citation: (Ismail et al., 2021)

To Cite this Article: Ismail, Z., Amin, W. A. A. W. M., \& Derahman, A. (2021). The Synergy of Distributed Leadership towards District Education Office Performance. International Journal of Academic Research in Business and Social Sciences, 11(8), 381-389.

Copyright: (c) 2021 The Author(s)

Published by Human Resource Management Academic Research Society (www.hrmars.com)

This article is published under the Creative Commons Attribution (CC BY 4.0) license. Anyone may reproduce, distribute, translate and create derivative works of this article (for both commercial and non-commercial purposes), subject to full attribution to the original publication and authors. The full terms of this license may be seen at: http://creativecommons.org/licences/by/4.0/legalcode

Vol. 11, No. 8, 2021, Pg. 381 - 389

Full Terms \& Conditions of access and use can be found at http://hrmars.com/index.php/pages/detail/publication-ethics 


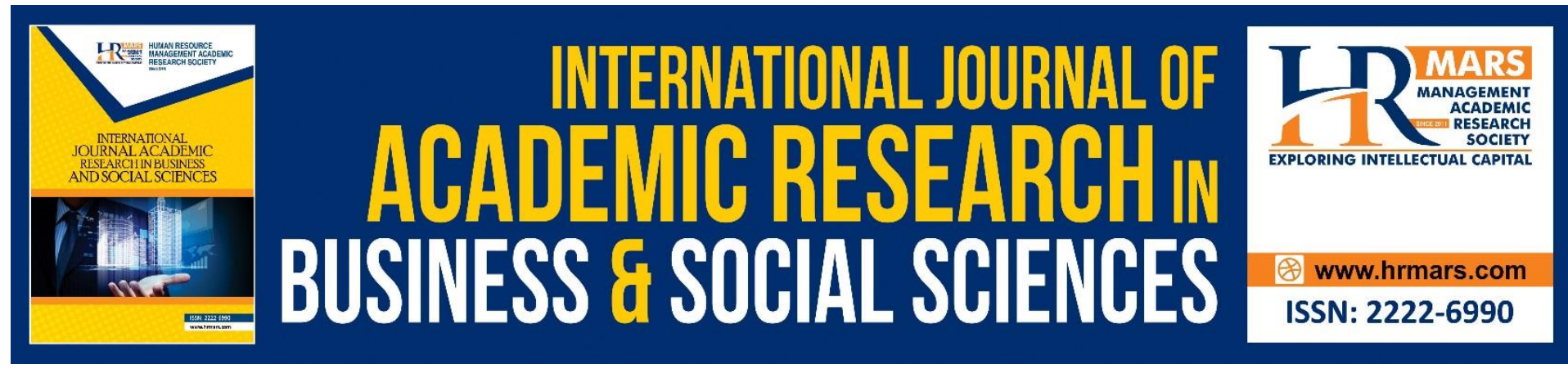

\title{
The Synergy of Distributed Leadership towards District Education Office Performance
}

\author{
Zahariah Ismail, Wan Abd Aziz Wan Mohd Amin, Abdullah \\ Derahman \\ Universiti Sultan Zainal Abidin, Terengganu, Malaysia.
}

\begin{abstract}
The purpose of this paper is to focus on distributed leadership in District Education Office and explore the impact arising from this practice of leadership for those in formal leadership positions towards District Education Office (PPD) Performance. The "6's shifts" of the Malaysian Education Development Plan (PPPM) 2013-2025 aims to empower JPNs, PPDs and schools to customize solutions based on need and also to improve the access, quality, equity, unity and effectiveness of the delivery system to implement better policies. In studying the relationship between distributive leadership synergy with organizational performance, PPD organizational performance is measured through verification of PPD Excellence Rating based on three dimensions namely 1 ) leadership, 2) organization, and 3) output. The paper draws upon a wide range of research literature to explore the available empirical evidence about distributed leadership and organizational outcomes. The analysis focuses particularly on the evidence based concerning distributed leadership and District Education Office excellence. This analysis of the available evidence highlights the potential for distributed leadership to make a difference to organizational change and improvement. It suggests that principals need to relinquish power and authority; that there is an inevitable shift away from leadership as position to leadership as interaction and that principals will need to build a high degree of reciprocal trust to negotiate successfully the fault lines of formal and informal leadership practice. The paper contributes a contemporary overview of literature about the impact of distributed leadership and analysis the implications for the role of the District Education Office performance. So, the indicator of change in this concept paper such as input, activities, output, outcome and impact will be the fundamental aspect to enhance PPD's empowerment as a learning organization and continuous professional development. This study contributes to existing knowledge by practicing distributive leadership and its impact on PPD excellence ratings in the state of Kelantan. In addition, this study has important implications in understanding the synergy of distributive leadership in education management in Malaysia in general.
\end{abstract}

Keywords: Distributed Leadership, District Education Office Performance

\section{Introduction}

Distributed leadership is increasingly been seen as a contributor to organizational growth and success. From a distributed perspective, it is the nature and the effects of leadership practice 
that matter. Knowing if, how and in what way distributed leadership practice influences organizational outcomes is at the heart of a great deal of contemporary empirical enquiry (Leithwood et al., 2009; Harris, 2009). Contemporary evidence tends to support a positive relationship between distributed leadership, organizational improvement and student achievement (Harris, 2009; Hallinger and Heck, 2009; Leithwood and Mascall, 2008; Harris, 2008). These studies have underlined and reinforced the importance of distributed leadership as a potential contributor to positive organisational change and improvement towards District Education Office (PPD) Performance. However, till now no indicator that measure the successful of District Transformation Programme (DTP) and PPD as a learning organization practicing distributed leadership affected to District Education Office (PPD) Performance. So, the indicator of change in this concept paper such as input, activities, output, outcome and impact will be the fundamental aspect to enhance PPD's empowerment as a learning organization and continuous professional development. The definition of organizational performance is a surprisingly open question with few studies using consistent definitions and measures (Kirby, 2005). Performance is so common in management research that its structure and definition are rarely explicitly justified; instead, its appropriateness, in no matter what form, is unquestionably assumed (March \& Sutton, 1997). How distributed leadership explains much of its subsequent effect, for good or ill, on the organization. We need to know much more about the patterns of distribution and to understand which configurations are most likely to have a positive impact on the organizational performance through District Education Office Excellence Rating (PKPPD).

\section{The District Transformation Program (DTP)}

DTP is based on the concept of support and accountability with four main components.

1. Empower local leadership in the first quarter it touched on the role of MOE in empowering local leadership. In this context, the MOE has revised its existing roles and responsibilities to provide clearer delivery channels from the central level to the school level. The role of JPN and PPD has changed to be redefined to give them more rights to make decisions and interact directly with the school. This increased operational flexibility allows JPN and PPD to adapt policies and programs that better meet the specific needs of their schools. The Ministry maintains the functions of policy formulation and macro planning. The State Department of Education focuses on the coordination and delivery of plans, becoming an important liaison between policy makers and implementers at the lower levels. Meanwhile, the District Education Office acts as a school assistant and monitor.

2. Provide support to organizations that need it most The second quarter of the DTP component touches on the role of KPM, JPN and PPD in providing support to the school organizations that are most in need. Based on data analysis and root causes, PPD develops local interventions and solutions that meet the needs of schools to address various issues and challenges. Position. The School Improvement Partner (SIPartners+) was created to provide guidance and support to Principals and Headmasters towards improving the quality of leadership and organizational management. The position of School Improvement Specialist Counsellor (SISC +) was created to guide teachers towards improving the quality of teaching, and to improve understanding of policies, new curriculum and assessment to supervised teachers.

3. Attract access, quality, and equity the third component of the DTP touches on aspects of access, quality and equity of education. The educational transformation planned in the Malaysian Education Development Plan is arranged in three waves in line with the 
improvement of system capabilities and capabilities as well as based on targeted and clear objectives. All districts and schools remain in line with the Ministry's strategic priorities with standard Key Performance Indicators (KPIs). An integrated education database is created so that performance analysis up to school level can be accessed quickly through an integrated dashboard. PPD Excellence Assessment is conducted to identify the level and potential of PPD in terms of leadership, organizational management and success. This assessment is implemented to identify best practices and aspects of continuous improvement among PPDs so that focused support and intervention can be channelled to the PPDs most in need.

4. Discipline of monitoring, problem solving, and action taking Performance dialogue is established as a monitoring mechanism at every level to ensure that schools, districts and states are on the right track. The performance dialogue discusses educational performance based on data and facts to identify strengths and weaknesses, followed by a review of the implementation plan and followed by robust and focused actions to achieve KPI targets.

\section{Organizational Performance}

District Education Office Performance Rating (PKPPD) in 2018, PKPPD was conducted to identify the level of each PPD throughout Malaysia. A total of 140 out of 143 PPDs (98\%) achieved the minimum standard of PKPPD, with 73 PPDs (51.05\%) achieving above the minimum standard. Rating verification is conducted by a qualified Auditor General MS ISO 9001: 2015. The results of the rating are used as a reference for PPD to improve performance based on weaknesses in the rated components. Rating and verification of the District Education Office (PKPPD) Excellence Rating based on the following 3 dimensions: Dimension 1: Leadership (30\%) Dimension 2: Organization (50\%) Dimension 3: Output (20\%).

\section{Types of Performance Measures}

1. Dimension 1: Leadership (30\%)

(D1: 1.1.1) Focused on Feedback Ability to monitor and analyze feedback. a) Performance Dialogue b) MB meeting c) Customer MB - Involves all MB meetings Customer MB presentation meeting

(D1: 1.1.2) Professional Development The ability to control the development of professionalism leads to the achievement of organizational objectives. Focused Guidance Ability to control the implementation of coaching in a planned and effective manner involves guidance made by * all PPD officers in the school * (except SIPartners + , and SISC + )

(D3: 3.1.1) Integrated Assessment of Education Service Officers (PBPPP / LNPT Cumulative) PBPPP / LNPT Assessment (calculation of average achievement of all officers in PPD)

(D1: 1.1.4) Action Focus Ability to monitor and evaluate the effectiveness of actions taken * Focus on audit findings, inspection findings, monitoring / inspection findings and guidance findings

(D1: 1.2.1) Coaching and Mentoring Commit to * coaching and mentoring (CM) activities to solve problems and improve school achievement * (Focuses on SIPartners + , and SISC +)

(D1: 1.2.2) Physical Provide support by providing and maintaining * physical facilities to create a conducive school environment.

(D1: 1.2.3) Human resources Monitor and control the use of * human resources holistically to help achieve system aspirations and student aspirations.

(D1: 1.2.4) Expertise Network Support and control the creation of cooperation / collaboration / smart partnership between the organization of officers and external parties in the field of work such as curriculum, co-curriculum, HEM and other related activities. 
(D1: 1.3.1) Organizational Strategic Planning Control the strategic planning process of the organization using data

(D1: 1.3.2) Monitoring and Evaluation Monitor and evaluate the implementation of processes in accordance with established procedures to achieve objectives or goals

(D1: 1.4.1) Data focused Monitor the decision-making process and manage based on data (D1: 1.4.2) Data diversity (Big data) Control the process of analysing and translating various data to be used as input to the organizational action plan.

\section{Dimension 2: Organization (50\%)}

(D2: 2.1.1) Focused on Feedback Ability (MB) to monitor and analyse feedback, Performance Dialogue, MB meeting, Customer MB involves all meetings managed by PPD.

(D2: 2.1.2) Professional Development Ability to set goals, plan, translate guidance into practice and evaluate the effectiveness of guidance.

(D2: 2.2.1) Coaching and Mentoring Commit to * coaching and mentoring (CM) activities to solve problems to improve school achievement * Focuses on SIPartners + and SISC +.

(D2: 2.2.2) Physical Provide support by providing and maintaining physical facilities (infrastructure and teaching aids) to create a conducive school environment.

(D2: 2.2.3) Human resources Optimizing the use of * human resources holistically to help achieve system aspirations and student aspirations. - Human resources include PPD staff and schools

(D2: 2.2.4) Expertise Network Support and control the creation of collaborative (e.g. smart partnerships between officer organizations and external parties in areas of work such as curriculum, co-curriculum, HEM and other related activities).

(D2: 2.3.1) Organizational Strategic Planning Ability to make structured and focused intervention planning using data.

(D2: 2.3.2) Monitoring and Evaluation Ability to make organizational strategic planning using data.

(D2: 2.4.1) Data focused Manage data efficiently and effectively in meeting organizational objectives. (D2: 2.4.2) Data diversity (Big data) Analyse and translate various data to be used as input to the organizational action plan.

\section{DIMENSION 3: OUTCOMES (20\%)}

\section{Dimensional Information}

D3: 3.1.1: Integrated Assessment of Education Service Officers (PBPPP / LNPT Cumulative) PBPPP / LNPT Assessment (calculation of average achievement of all officers in PPD)

D3: 3.1.2: Integrated Assessment of Education Service Officers - Outcomes (Cumulative)

D3: 3.2.1: SKPMg2 Standard 1 to Standard 5 Weighted score set in SKPMg2 which is average achievement of all schools.

- Standard 1 - Leadership

- Standard 2 - Organizational Management

- Standard 3 - Curriculum Management, Co-curriculum and Sports, and Student Affairs

- Standard 4 - Teaching and Facilitation

- Standard 5 - Student Development 
Verification aspects involves all PPD staff assessed by PPD including PPD Chairman, PPD Deputy, SIP + / SISC +, PPD Officer and Anggota Kumpulan Pelaksana (AKP). The average SKPMg2 scores of all school years were assessed.

D3: 3.2.2 Pelibatan Ibu Bapa, Komuniti dan Sektor Swasta dalam Pendidikan (PIBKS) Percentage of schools that achieved $65 \%$ attendance of parents and community to school for the following 5 activities: Registration Day, Parents Teachers Association (PTA) General Meeting, Reporting Day, Annual Sports Day, Awards Day. Percentage of schools achieving 65\% average attendance for 5 main activities. Review of e-PIBKS system and school percentage calculation record using calculation formula: The e-PIBKS system and school percentage calculation record reach $65 \%$ (Data from e-PIBKS)

D3: 3.2.3 Satisfaction of customers who receive JPN / PPD services Percentage of customers who receive services from JPN / PPD give a good score / agree in all aspects of service evaluation Customer evaluation to all JPN officers / Customer evaluation to all JPN / PPD officers for all services provided PPD for all services provided, review of service feedback forms, calculation of customer percentage, form filled by customer for each service, record analysis and minutes of meetings.

D3: 3.3.1 JPN / PPD Level Recognition Obtained district or state or national or international level recognition from the aspects of curriculum, co-curriculum, HEM and management at JPN / PPD level. Achievements and recognition received by JPN / PPD for aspects of curriculum, co-curriculum, HEM and management for the year under review, checks are made on certificates / proof of recognition, review of reporting / participation, analysis of achievement data, letter, certificate and related documents.

D3: 3.3.2 School Level Recognition District or state or national or international level recognition in terms of curriculum, co-curriculum, HEM and school level management, achievements and recognition received by JPN / PPD for aspects of curriculum, co-curriculum, HEM and management for the year under review. Review of copies of certificates / documents received from any school in JPN / PPD, letter, certificate, related documents.

\section{Findings}

Interpretation of correlation values in this study will use the value coefficient of correlation coefficient Perason $r$ as shown in table 1 below is used to answer the 3rd research question whether there is a significant relationship between distributed leadership and District Education Office Performance Rating (PKPPD) based on the following justifications:

Table 1: Interpretation of correlation values in this study will use the value coefficient of correlation coefficient Perason $r$

\begin{tabular}{|ll|} 
Value of Correlation Coefficient ( $r)$ & Interpretation of Coefficient \\
$0.01-0.09$ & Neglected \\
$0.10-0.29$ & Low \\
$0.30-0.49$ & Simple \\
$0.50-0.69$ & Strong \\
$0.70-0.99$ & Very High \\
1.00 & Perfect \\
\hline
\end{tabular}

Source: Davies, I.I.C. 1971. The Management of Learning. London: C. Gain 
Table 2: Relationship between distributive leadership and District Education Office Performance in Kelantan

\begin{tabular}{|c|c|c|c|}
\hline \multicolumn{4}{|c|}{ Correlations } \\
\hline & & PartBdistributed & $\begin{array}{c}\text { PartDperformanc } \\
\text { e }\end{array}$ \\
\hline PartBdistributed & $\begin{array}{c}\text { Pearson } \\
\text { Correlation } \\
\end{array}$ & 1 & $.813^{* *}$ \\
\hline & Sig. (2-tailed) & & .000 \\
\hline PartDperformance & $\begin{array}{c}\text { Pearson } \\
\text { Correlation }\end{array}$ & 278 & 278 \\
\hline & Sig. (2-tailed) & $.813^{* *}$ & 1 \\
\hline & N & .000 & 278 \\
\hline
\end{tabular}

Table 1 above illustrate the significant relationship of distributed leadership inventory with PPD Performance Rating in Kelantan. The results show that there is a significant relationship between distributed leadership (IV) and PPD Performance Rating (DV) that is the value of $r=$ $.813^{* *}$, sig $=.000(p<.005)$ this relationship is a strong relationship. Since the relationship between the two variables is a positive relationship, it carries the meaning of higher Distributed Leadership (IV) practise, then also higher to PPD Performance Rating (DV).

\section{Conclusions}

District education offices focus on excellence and performance the District Education Officer controls the whole district with regard to education, manage, guide, hear and redress the complaints of the teachers, other staff and general public. All the duties by the other staff are complied with under the name of District Education Officer. The Deputy Education Officers work under the guidance of District Education Officer and comply all the duties which are given by the District Education Officer. Optimisation of human capital resources, communication and interaction between headmasters, teachers, students, parents and high achievers in society have propelled schools in Kelantan towards excellence. The District Education Office, led by 10 District Education Officer, looks after 2,032 teachers and 22,481 students in 2019. District Education Officers have been empowered to monitor and assist the Education Ministry's ongoing enforcement exercise.

\section{Acknowledgement}

All praise be to Allah SWT God of all the worlds, blessings and peace be upon the great Prophet Muhammad S.A.W. as well as family and friends. My highest appreciation goes to Professor Dr. Wan Abd Aziz bin Wan Mohd Amin as my Supervisor and Co-Supervisor Dr Abdullah bin Derahman who has given a lot of guidance, support, assistance, and encouragement until the completion of this study. Next thanks to the Dean and all the lecturers of the Faculty of Applied Social Sciences (FSSG) Sultan Zainal Abidin University (UniSZA) who helped a lot either directly or indirectly. Appreciation is also extended to the District Education Office and the Kelantan State Education Department for their support in conducting studies at all district education offices in the state of Kelantan. Thanks also to the district education officers as well as in all District Education Offices in the state of Kelantan who made this study a success. 
Finally for the special family of special parents who never forget to pray. To my loyal husband Abdul Aziz bin Mamat and my lovely precious one Muhammad Mifzal Alzam, Nur Arina Nasuha, Muhammad Adam Mukhriz and Muhammad Rayyan Darwisy who always very patient. Not forgetting the friends who helped and the lecturer especially Dr Nurul Fadly Habidin, Sultan Idris University of Education.

\section{Corresponding Author}

Zahariah binti Ismail

Applied Social Sciences Faculty, Universiti Sultan Zainal Abidin, Gong Badak Campus, Terengganu, Malaysia

zaharriyah@gmail.com

\section{References}

Akdere, M., Egan, T. (2020). Transformational Leadership and Human Resource Development: Linking Employee Learning, Job Satisfaction, And Organizational Performance. Human Resource development quarterly. 31 (4), 393-421.

Al-Jedaiah, M. N., Albdareen, R. (2020). The Effect of Strategic Human Resources Management (SHRM) on Organizational Excellence. Problems and Perspectives in Management. 18 (4), 49-58.

Antony, J. P., Bhattacharyya, S. (2010). Measuring Organizational Performance and Organizational Excellence of SMEs - Part 1: A conceptual framework. Measuring Business Excellence. 14 (2), 3-11.

Camburn, E., and Han, S. W. (2009). Investigating Connections Between Distributed Leadership and Instructional Change, in Harris, A., Distributed Leadership: Different Perspectives. Springer, Amsterdam.

Creswell, J. W. (2002). Educational Research-Planning, Conducting, And Evaluating Quantitative And Qualitative Research (2nd Ed). New Jersey: Pearson Merril Prentice Hall.

Creswell, J. W. (2005). Educational Research - Planning, Conducting, And Evaluating Quantitative And Qualitative Research (3rd Ed.). New Jersey: Pearson Merril Prentice Hall.

Cronbach, L. J. (1946). Response sets and test validity. Educational and psychological measurement, 6, 672-683

Day, C., Sammons, P., Leithwood, K., Harris, A., and Hopkins, D. (2009). The Impact of Leadership on Pupil Outcomes, Final Report. DCSF. London.

Fitzgerald, T., \& Gunter, H. (2006). Teacher Leadership? A New Form of Managerialism. New Zealand Journal of Educational Leadership, 21(2),44-57.

Hallinger, P. (2009). Assessing the Contribution Of Distributed Leadership To School Improvement And Growth In Math Achievement. Paper presented at AERA Conference.

Hallinger, P., and Heck, R. (2009). Distributed Leadership in Schools: Does System Policy Make a Difference?. in Harris, A. (Ed.), Distributed Leadership: Different Perspectives, Springer, Amsterdam.

Hargreaves, A., \& Fink, D. (2009). Distributed leadership: democracy or delivery?, in Harris, A., Distributed Leadership: Different Perspectives, Springer, Amsterdam.

Harris, A. (2007). Distributed Leadership: Conceptual Confusion and Empirical Reticence. International Journal of Leadership in Education, 10(3), 1-11. 
Harris, A. (2008). Distributed Leadership: Developing Tomorrow's Leaders. Routledge: London.

Harris, A. (2009). Distributed Leadership: Different Perspectives. Springer: Amsterdam.

Hester, H., \& Geert, D. (2010). How Distributed Leadership Can Make A Difference In Teachers' Organizational Commitment? A qualitative study. Teaching and Teacher Education 26(3), 565-575.

Kaczmarczyk, S., Murtough, J. (2002). Measuring The Performance Of Innovative Workplaces. Journal of Facilities Management, 1 (2), 163-176.

Kementerian Pendidikan Malaysia (2013). Pelan Pembangunan Pendidikan Malaysia 2013 2025 - Putrajaya: KPM.

Leithwood, K., and Mascallm, B. (2008). Collective Leadership Effects on Student Achievement. Educational Administration Quarterly, 44(4), pp. 529-61.

Leithwood, K., Mascall, B., and Strauss, T. (2009). Distributed Leadership According to the Evidence. Routledge, London.

Mayrowetz, D. (2008). Making Sense of Distributed Leadership: Exploring the Multiple Usages of the Concept in the Field. Educational Administration Quarterly, 44(3), 42435.

Murphy, J., Smylie, M., and Louis, S. K. (2009). The Role Of The Principal In Fosteringthe Development Of Distributed Leadership. School Leadership \& Management, 23(9).

Pallant, J.( 2001). SPSS Survival Manual - A Step By Step Guide To Data Analysis Using SPSS for Windows (version 10). Buckingham Open University Press.

Spillane, J. P. (2006). Distributed Leadership. Jossey-Bass: San Francisco.

Spillane, J. P., \& Camburn, E. (2006). The Practice Of Leading And Managing: The Distribution Of Responsibility For Leadership And Management In The Schoolhouse. Paper presented at AREA Annual Meeting, San Francisco, CA.

Spillane, J., Halverson, R., \& Diamond, J. (2001). Making Sense Of Distributed Leadership: Exploring The Multiple Usages Of The Concept In The field. Institute for Policy Research working article.

Woods, P. A., \& Gronn, P. (2009). Nurturing Democracy: The Contribution Of Distributed Leadership To A Democratic Organizational Landscape. Educational Management Administration and Leadership, 37, 430-451. 